http://dx.doi.org/10.4314/gjl.v4i2.4

\title{
A SOCIOPHONETIC STUDY OF YOUNG NIGERIAN ENGLISH SPEAKERS
}

\author{
Rotimi O. Oladipupo and Adenike A. Akinjobi
}

\begin{abstract}
This study examines the variable use of r-liaison and boundary consonant deletion processes in the speech of young Nigerian speakers of English. This is with a view to confirming the hypothesis that continuous speech processes (CSPs) can be socially differentiated in a speech community. A sample of 180 young educated Nigerian English (NigE) speakers, evenly stratified into gender and class, voiced 19 utterances and a short passage into digital recording devices and filled in 180 copies of a structured questionnaire. All tokens of r-liaison and consonant deletion produced at word and morpheme boundaries were identified and analysed statistically, using the Analysis of Variance (ANOVA). The only speech variation observed in the data was between male and female speakers in boundary consonant deletion, $(\mathrm{F}(1$, 176) $=6.24, \mathrm{p}=.013)$. The findings did not sufficiently demonstrate variability in the speech patterns of young NigE speakers in relation to $r$ liaison and boundary consonant deletion processes.
\end{abstract}

Key words: connected speech, sociophonetics, r-liaison, boundary consonant deletion, Nigerian English.

\section{Introduction}

Elaborate attention has not been paid to social variation research in the L2 varieties of English (Huber and Brato 2008). In Nigeria, for instance, most variationist studies have been confined to the level of education or region of speakers (Brosnahan 1958, Jibril 1982, Sogunro 2012). This is not unconnected with the cynicism of scholars on the applicability of the Labovian model to the multilingual environment of most L2 societies.

First, Labov's studies were carried out among native speakers who were mainly monolinguals, and so there was no issue with the speakers' mastery of the language. Second, the kind of elaborate social class system upon which his studies 
were based is non-existent in Nigeria. Besides, factors like wealth and political status do not usually correlate with competence in the use of English in the L2 setting, as education is not necessarily a key factor of success.

Nevertheless, all aspects of the Labovian model and its methods are very relevant to the Nigerian sociolinguistic environment. In the first instance, its ethnic/regional approach to variation is appropriate in Nigeria which is made up of different ethno-linguistic groups. This is because speech production can vary according to ethnicity or region of speakers (Guy 1981, Horvath 1985, Jibril 1979, 1982; Labov 1966, Trudgill 1974). Again, Labov's (1963, 1966, 1990, 1991) position that speakers' gender and age are key factors of speech variation is relevant to any speech community, given human biological and cultural differences.

Lastly, although social class is much more pronounced amongst the native speakers of English, it cannot be completely discountenanced in the L2 setting. The reason is that class difference is inherent in every society, though at varying levels and in terms of different factors ranging from economic to cultural and political, and Nigeria cannot be an exception. The Nigerian society, for instance, is essentially polarised into haves and have-nots on the basis of economic and political advantages that a class has over the other. This determines to a large extent the quality of education, level of social exposure and opportunities available to members of each class, which may, in turn, influence their speech.

Given the above scenario therefore, it becomes imperative to begin to pay attention to class as a social variable in the L2 setting. This is the course this study attempts to chart by examining the use of r-liaison and boundary consonant deletion processes in the speech of young Nigerian speakers of English in order to establish possible correlations of these features with gender and social class in NigE.

\section{Research Questions}

The study intends to answer the following research questions:

(a) Do gender and class variations exist in young NigE speakers' use of the r-liaison process?

(b) Does the boundary consonant deletion process correlate with gender and social class of young NigE speakers?

\section{Connected Speech Processes}

Words are not usually spoken in isolation but in a fluent continuous stream. In connected speech therefore, discreteness of segments marked by phonemes is usually neutralised, as sounds tend to slur into one another (Pike 1948). Adjacent segments do influence each other in varying degrees, especially at morpheme and word boundaries in rapid, casual speech (Nolan and Kerswill 1990, Roach and Widowson 2001). The 
modifications that occur to segments in fluent speech may be phonemic alterations or simple allophonic realisations whereby less prominent consonants, vowels, or syllables in words are altered or deleted; contiguous sounds resemble each other, or a sound is inserted into another (Kerswill 1985). Sometimes, the resultant sound may even be alien to the phonemic inventory of the language in question. Nolan and Kerswill (1990) buttress this claim with the example of an English utterance: I don't suppose you could make it for five, transcribed phonemically as /ai deunt səpəuz ju: kod meik it fo: faiv/, but which becomes [nspeuzxebme:xiffaiv] through the processes of reduction, lenition, assimilation and deletion when rendered in rapid speech.

These processes by which the explicit, dictionary-type forms of sounds are converted to the phonetic properties of fluent speech by a variety of reduction and simplification processes (Nolan and Kerswill 1990) are what are technically referred to as connected speech processes (CSPs). Among these are assimilation, reduction, elision (deletion), lenition, liaison (linking), epenthesis (insertion), juncture, and so forth.

The occurrence of CSPs has largely been traced to a number of sources. One of them is articulatory economy, which is an attempt to maximise articulatory ease when pronouncing adjoining sounds in connected speech (Abercrombie 1967, Foulkes 2006). It has been established that very fast speech may lead to articulation of shorter duration, increased overlap, and greater articulatory undershoot (Foulkes 2006).

On the contrary Ohala (1983) is of the opinion that changes in speaking rate cannot affect all sounds equally, since the degrees of inertia and speed movement of the articulators are not the same. He believes that CSPs are rather products of limitation of the speech mechanism and/or operations of aerodynamic principles in the vocal tract. In other words, these processes result from variation in the structures of the vocal tract. Citing the example of stops which usually change to affricate in the environment of close vowels or palatal / j/ (e.g. the pronunciation of tune as [ $\mathrm{f} \mathrm{un}]$ in some varieties of British English), he argues that such sound change is not articulatorily motivated but is due to the aerodynamics of the vocal tract setting.

Again, the idea of mechanical determination of CSPs has been proved inadequate. CSPs have been discovered to differ from one language, dialect or individual to another (Byrd 1994; Laver 1994); whereas, the innate constraints of the vocal tracts are universal (Foulkes 2006). For instance, regressive voicing assimilation is not permitted in RP, whereas it is found in some Scottish accents (e.g. the medial consonant cluster in birthday may be pronounced [-ðd-]) and in French (e.g. /avek/ may become [aveg] in "avec vous" [aveg vu]). CSPs, then, are determined by language-specific rules which dictate what particular processes are to be allowed in a particular language or dialect (Byrd 1994, Kerswill 1987, Laver 1994, Nolan \& Kerswill 1990). 
It is for this reason that Kerswill $(1985,1987)$ opines that CSPs can be socially differentiated depending on regional affiliation, age, sex and socio-economic class of speakers; and may be employed or avoided by members of a particular sociolinguistic group. This study, therefore, attempts to examine such variation in two connected speech processes (r-liaison and boundary consonant deletion) among young NigE speakers, differentiated by gender and social class.

\section{R-liaison in Nigerian in English}

R-liaison and consonant deletion are two of the connected speech processes found at varying degrees in NigE. R-liaison, comprising linking and intrusive $/ r$, refers to insertion of $/ \mathrm{r} /$ in-between two adjacent vowels to fill a hiatus at word boundary for euphonic purposes (Oladipupo 2014a, Skandera \& Burleigh 2005). In linking $/ \mathrm{r} /$, an orthographic $r$ is articulated in-between the contiguous vowels, e.g. for ever [frə və], after a while [æftrə waIl]; while $r$ is absent but pronounced in the same position in intrusive /r/, e.g. media event [mi:dıər Ivent], idea of [aidıər əv].

In NigE, r-liaison is not so pervasive. The few scholars (e.g. Awonusi 2004, Oladipupo 2014a, b; Simo Bobda 2007) who have attempted to explore its operation are unanimous that this feature of speech is not heard very often among NigE speakers. Awonusi (2004), for instance, is of the view that the linking / $\mathrm{r} /$ usage in Nigerian English Accent is consistent with RP only in such short phrases as for $a$ while, here and there, after all, etc., while the intrusive $/ \mathrm{r} /$ is not found at all. This sentiment is also shared by Simo Bobda (2007) who claims that NigE does not observe the r-insertion rule (the phonological rule governing applications of linking / $\mathrm{r} /$ at word boundaries in RP) as found in words like four o 'clock [fo: pklpk], and far away [fa: əwer].

Oladipupo (2014a) identifies linking and intrusive /r/ as connected speech processes found in NigE but categorises them as minor processes used sparingly by a minority of speakers in Nigeria. He attributes the low occurrence of r-liaison to the tendency for NigE speakers to pronounce every word as distinct as possible in connected speech (due to the syllable-timed rhythm of NigE where each syllable tends to occur at regular time intervals) and a lack of awareness for the speech feature in NigE.

However, Oladipupo (2014b) does not only establish the claim that r-liaison is scarcely found in NigE, he also examines further its social and linguistic distribution in educated Yoruba English (EYE), a sub-variety of NigE, and finds that the feature shows evidence of social and linguistic patterning. It correlates with the adults' speech and occurs, predominantly, in-between grammatical items, such as there are, more of you and after a while, where the feature has been lexicalised due to continuous use. In 
view of this discovery, the present study extends inquiry into the social variation of $r$ liaison to representatives of young speakers in the entire country.

\section{Consonant Deletion in Nigerian English}

Boundary consonant deletion is a process by which consonant clusters at word or morpheme boundaries are simplified in connected speech by deleting one or more of the clusters to maximise ease of articulation, e.g. [faun farv] found five, [dz $\Lambda \mathrm{s}$ w $\Lambda \mathrm{ns}]$ just once.

Previous studies are agreed that the consonant deletion process is a common phenomenon in NigE (Jibril 1982, Oladipupo 2014c) and indeed in African English accents generally (Simo Bobda 2007). Citing instances of postvocalic, syllable/word final and coda cluster deletion of certain consonants (e.g. [sistr] sixty, [t]arl] child, [ə

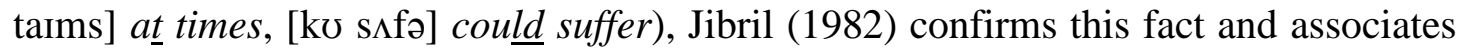
the trend with fast speech or the need for consonant cluster simplification (the need to reduce a cluster of consonants word-internally or at a boundary).

Oladipupo (2014c) is also of the opinion that NigE, like many other varieties of English (native and non-native), tends towards elision of consonants at word and morpheme boundaries, especially at the coda position of the first of two contiguous words, e.g. [kep kwaiət] kept quiet, [dəon bai] don't buy. He, however, attributes this trend to consonant cluster reduction, rather than fast speech. The present study, however, is an attempt to examine the social distribution of this feature of speech amongst young Nigerian speakers which previous studies did not pay attention to.

\section{Sociophonetic Variation}

While sociolinguistics deals with all aspects of language variation, sociophonetics studies only socially-conditioned phonetic variation in speech that correlates with social factors like speaker's gender, age or social class (Honey 1997, Foulkes and Docherty 2006). The goal of sociophonetic research is to blend both sociolinguistic and phonetic methods, techniques and principles with a view to establishing that language variation is not only systematic but also embedded with social meaning (Hay and Drager 2007). In doing this, sociophonetic work has been interacting with other fields of study like first and second language acquisition, forensic linguistics, dialectology, conversation analysis and computational linguistics, among others (Foulkes and Hay 2015).

The emergence of this research tradition has been spurred by the view that language varies, especially at the phonetic level. It is generally held that speech variability may be influenced by speakers' social backgrounds - gender, age, social class and ethnicity (Labov 1966, McCarthy 2012). But beyond these factors, variation 
in speech has also been accounted for by groups and social networks affiliation (Milroy 1987, Eckert 2000) and communicative context which comprises linguistic style or register of speech, social context, the topic of discussion, the addressee and the intention of the speaker (Foulkes 2006).

Sociophonetic research is not limited to speech production, but also extends to speech perception (Foulkes 2006, Clopper \& Pisoni, 2005, Thomas 2002). Specifically, extensive work has been done on segmental variation from both auditory and acoustic perspectives (e.g. Alan and Stuart-Smith 2011; Kendall \& Fridland 2011, Schrimpf 2013). A few studies have also been conducted to capture regional and social speech variation at the suprasegmental level, especially on aspects of intonation (Warren 2005), rhythm (Carter 2005) and tonal alignment (Nolan 2002). Sociophonetic variation has also been reported in the subsegmental aspects of speech, in forms of the relative duration, strength or temporal coordination of articulatory gestures (Docherty \& Foulkes 2005, Foulkes \& Docherty 2006, Nolan \& Kerswill 1990, Scobbie 2005).

In NigE, studies that employ the sociophonetic tradition to examine the subsegmental features of connected speech are very scarce. This study, therefore, is an attempt to explore this research dimension. The focus on young speakers is motivated by the fact that they are usually regarded as linguistic innovators and agents of change, and their speech patterns can provide insight into the direction of sound change in a speech community (Kerswill 1996).

\section{Methodology}

A sample of 180 young educated NigE speakers (between 18 and 35 years) was drawn, through stratified and purposive techniques, from the six geo-political zones in Nigeria (North West, North East, North Central, South West, South East and South-South). This was with a view to selecting participants who are representative of young speakers of English across the entire country.

The participants comprised students of public and private higher institutions as well as members of the National Youth Service Corps (fresh graduates observing the one-year mandatory service to the nation) in those parts of the country. The choice of students and graduates was motivated by the need to sample educated speakers for the research. The young speakers so selected from all the geo-political zones were stratified into gender and social class without consideration for their ethnic backgrounds (male-low class: 45 speakers; male-high class: 45 speakers; female-low class: 45 speakers; female-high class: 45 speakers).

Their social class statuses were determined based on such indices as family socio-economic background, parents' occupation, school type (high fee-paying private university or low-cost public university), access to wealth and international exposure; 
all derived from the questionnaires administered to each of them. For instance, the parents of high social class speakers were high-ranking entrepreneurs, professionals and senior management staff of their organisations. The high social class participants themselves were undergraduates and graduates of high fee-paying private universities in Nigeria, and had had the privilege of travelling to Europe and the Americas for the summer on several occasions; a fact that lends credence to their parents' class status. Parents of participants in the low social class category, on the other hand, were lowincome earners, while the speakers themselves were not as privileged as the other group.

The researcher and his trained research assistants visited the participants in their various institutions and places of primary assignment and administered to them, on one-on-one basis, 180 copies of a structured questionnaire and a test comprising 19 utterances and a short passage (see the Appendix), both containing potential r-liaison and boundary consonant deletion sites. The questionnaire was meant to verify and identify their social backgrounds (whether male or female; low or high social class).

Having been informed of the purpose of the research and assured of the confidentiality of their responses, they were instructed to voice, into digital recording devices, Test 1 as responses to certain questions from the researcher and produce Test 2 as naturally as possible. The initial attempt of each participant was recorded and then played back to verify whether the conversations sounded casual and natural enough. The final recording was made after that had been ascertained

\section{The Data}

The relevant items, extracted from Tests 1 and 2, are shown in Table 1 and Table 2 below.

Table 1. R-liaison process

\begin{tabular}{lc}
\hline Item & Liaison Type \\
\hline $\begin{array}{l}\text { Peter at } \\
\text { more of him }\end{array}$ & Linking /r/ \\
after a while & $"$ \\
their action & $"$ \\
wore a black dress & $"$ \\
inquire about & $"$ \\
colour of & $"$ \\
for all & $"$
\end{tabular}


there are "

over eat "

power-assisted

law and order Intrusive $/ \mathrm{r} /$

idea of it "

media event "

Table 2. Boundary Consonant deletion

\begin{tabular}{|c|c|c|c|}
\hline $\begin{array}{l}\text { doesn't she } \\
\text { test drive } \\
\text { fixed price } \\
\text { seemed glad }\end{array}$ & $\begin{array}{l}\text { won't do it } \\
\text { don't buy it } \\
\text { found five } \\
\text { robbed both }\end{array}$ & $\begin{array}{l}\text { kept quiet } \\
\text { jumped well } \\
\text { old man } \\
\text { advertised car }\end{array}$ & $\begin{array}{l}\text { exact colour } \\
\text { equipped with } \\
\text { cold launch }\end{array}$ \\
\hline
\end{tabular}

\section{Statistical Analysis and Results}

All cases of r-liaison (linking and intrusive /r/) and consonant deletion produced by the participants at morpheme and word boundaries were allotted 1 mark each, while absence of liaison and deletion was assigned 0 . The scores were analysed statistically, using the Analysis of Variance (ANOVA), based on gender and class of speakers. The two dependent variables (r-liaison and boundary consonant deletion) were analysed separately and their results were reported before discussion.

\section{R-Liaison}

In view of the small number of tokens of r-liaison produced by the participants, we decided to combine the individual scores for linking and intrusive $/ \mathrm{r} /$ for the purpose of calculating the mean scores for gender and class variables in $r$ liaison. Table 3 shows the breakdown of the mean scores.

Table 3. Mean scores for r-liaison by gender and class variables

\begin{tabular}{lrcc} 
& \multicolumn{3}{c}{ Class } \\
\cline { 2 - 3 } Gender & Low & High & Gender agg. means \\
\hline Male & 0.889 & 0.800 & 0.844 \\
Female & 0.822 & 1.044 & 0.933 \\
\hline
\end{tabular}


Class agg. means

0.856

0.922

Grand Mean

Table 3 suggests that only a little difference existed between male and female speakers. While the males had a mean score of 0.844 , the females' score was slightly higher (0.933). The same trend was found between the two social classes. The high class speakers had only a little higher mean score (0.922) than the low class $(0.856)$. In order to determine the significance of the results, therefore, a univariate Analysis of Variance (ANOVA) was carried out, with participants' scores as the dependent variable and gender and class as independent variables, using the IBM SPSS statistics 20 package. The ANOVA results are presented in Table 4 below.

Table 4. Results of ANOVA analysis for r-liaison

Tests of Between-Subjects Effects

Dependent Variable: R-liaison

\begin{tabular}{|l|r|r|r|r|r|}
\hline Source & $\begin{array}{c}\text { Type III Sum } \\
\text { of Squares }\end{array}$ & df & $\begin{array}{c}\text { Mean } \\
\text { Square }\end{array}$ & \multicolumn{1}{c|}{ F } & \multicolumn{1}{c|}{ Sig. } \\
\hline Corrected Model & $1.644^{\mathrm{a}}$ & 3 & .548 & .459 & .711 \\
Intercept & 142.222 & 1 & 142.222 & 119.120 & .000 \\
Gender & .356 & 1 & .356 & .298 & .586 \\
Class & .200 & 1 & .200 & .168 & .683 \\
Gender * Class & 1.089 & 1 & 1.089 & .912 & .341 \\
Error & 210.133 & 176 & 1.194 & & \\
Total & 354.000 & 180 & & & \\
Corrected Total & 211.778 & 179 & & & \\
\hline
\end{tabular}

a. R Squared $=.008$ (Adjusted R Squared $=-.009$ )

The ANOVA results in Table 4 confirmed absence of gender variation, $(\mathrm{F}(1,176)=0.298, \mathrm{p}=.586)$; class variation, $\mathrm{F}(1,176)=0.168, \mathrm{p}=.683$; and group interaction, $(\mathrm{F}(1,176)=0.912, \mathrm{p}=.341)$. This implies that no variation was found amongst the participants in r-liaison usage.

\section{Boundary Consonant Deletion}

The mean scores for the independent variables (gender and class) were calculated from the individual scores in boundary consonant deletion process. Table 5 shows the mean scores for each of the social variables. 
Table 5. Mean scores for consonant deletion by gender and class variables

\begin{tabular}{|c|c|c|c|}
\hline \multirow[b]{2}{*}{ Gender } & \multicolumn{2}{|c|}{ Class } & \multirow[b]{2}{*}{ Gender agg. means } \\
\hline & Low & High & \\
\hline Male & 8.844 & 10.178 & 9.511 \\
\hline Female & 8.756 & 8.356 & 8.556 \\
\hline Class agg. means & 8.800 & 9.267 & \\
\hline \multicolumn{4}{|c|}{$\begin{array}{l}\text { Table } 5 \text { reveals a considerable difference between male and female } \\
\text { participants in boundary consonant deletion. Aggregated mean scores of } 9.51 \text { for } \\
\text { males and } 8.56 \text { for females suggest that the incidence of boundary consonant deletion } \\
\text { was higher amongst male participants than female participants. On the other hand, the } \\
\text { class difference was smaller. While low class speakers had an aggregated mean score } \\
\text { of } 8.80 \text { the high class had 9.27. Table } 6 \text { below shows the results of ANOVA } \\
\text { performed to test the significance of these mean scores. }\end{array}$} \\
\hline
\end{tabular}

Table 6. Results of ANOVA analysis for boundary consonant deletion Tests of Between-Subjects Effects

Dependent Variable: Boundary Consonant Deletion

\begin{tabular}{|l|r|r|r|r|r|}
\hline Source & $\begin{array}{c}\text { Type III Sum } \\
\text { of Squares }\end{array}$ & df & \multicolumn{1}{c|}{$\begin{array}{c}\text { Mean } \\
\text { Square }\end{array}$} & \multicolumn{1}{c|}{ F } & \multicolumn{1}{c|}{ Sig. } \\
\hline Corrected Model & $84.689^{\mathrm{a}}$ & 3 & 28.230 & 4.286 & .006 \\
Intercept & 14688.200 & 1 & 14688.200 & 2230.263 & .000 \\
Gender & 41.089 & 1 & 41.089 & 6.239 & .013 \\
Class & 9.800 & 1 & 9.800 & 1.488 & .224 \\
Gender * Class & 33.800 & 1 & 33.800 & 5.132 & .025 \\
Error & 1159.111 & 176 & 6.586 & & \\
Total & 15932.000 & 180 & & & \\
Corrected Total & 1243.800 & 179 & & & \\
\hline
\end{tabular}

a. R Squared $=.068($ Adjusted R Squared $=.052)$

The results of ANOVA analysis in Table 6 above show that, at 0.05 significant level, there was a significant variation between the mean scores of male and female speakers relative to boundary consonant deletion, $(\mathrm{F}(1,176)=6.24, \mathrm{p}=.013)$; whereas, no significant class difference was found, $(\mathrm{F}(1,176)=1.49, \mathrm{p}=.224)$. This implies that male speakers significantly deleted consonants at word and morpheme 
boundaries more than female speakers, while both the low and the high class participants had equal tendency towards deletion. However, the table also reveals gender-class interaction effect, $\mathrm{F}(1,176)=5.13, \mathrm{p}=.025)$, which means that social class differed significantly between both sexes: male high, with a mean score of 10.178 , used boundary consonant deletion more than female high with 8.356 (see Table 5). This shows that the gender variation was due to differences between male and female high class speakers.

\section{Discussion and Conclusion}

The findings of this study have shown that neither gender nor class variation was found in the speech of the participants (young NigE speakers) relative to r-liaison usage, and that only the speech of male speakers, especially that of the high social class, was found to correlate with boundary consonant deletion. In the light of these findings vis-à-vis related submissions in sociophonetic research therefore, this study has not sufficiently demonstrated variability in the speech pattern of young NigE speakers in relation to r-liaison and consonant deletion.

To start with, it is usually claimed in the sociophonetic tradition that female speakers use more standard or prestigious speech variants and fewer low-status forms than males (Hudson 1996, Labov 1990), and that the speech of members of higher social classes correlates with the standard forms, while vernacular forms are most prevalent among the lower social classes (Labov 1966). In view of this, a higher usage of r-liaison (being a prestige variant) would have been expected not only from female speakers but also from high class participants. However, this was not the case, as neither gender nor class variation was exhibited in this CSP, which demonstrates an equal status for r-liaison usage amongst the participants, irrespective of gender and class.

This implies that young NigE speakers, regardless of their gender and class affiliations, do not differ in r-liaison usage. The educational advantage and social exposure of the high class over the low class does not, in any way, translate to superior performance in the use of this prestigious feature of speech. This trend, which corroborates Oladipupo's (2014b) earlier finding that r-liaison does not correlate with gender and class in educated Yoruba English (a sub-variety of NigE), cannot be separated from the fact that r-liaison is scarcely used in NigE, especially amongst young speakers who lack exposure to it both in school and in the community (Oladipupo 2014b, c).

The only variation observed in the whole data was found between male and female young speakers in boundary consonant deletion, where the male speakers deleted more boundary consonants than their female counterparts. Again, no variation was observed between low and high class speakers altogether, although the gender- 
class interaction showed significant variation between male high and female high class speakers; that is, male from high social class significantly used boundary consonant deletion more than females of the same social class.

The gender difference can be traced to the need to achieve articulatory economy on the part of male speakers. Elision is considered a phonetically motivated process that is characteristic of connected speech, in that it enhances the ease of articulation (Hannisdal 2006). That males significantly deleted more boundary consonants than females, therefore, implies that male speakers (especially from high social class) are more receptive to natural phonological processes and are articulatorily more economical than female speakers, who tend to be more careful and formal in speech (Labov 1963, 1966; Hudson 1996).

Overall, the study has demonstrated that Kerswill's $(1985,1987)$ observation that CSPs may be socially differentiated in a speech community is not fully supported in NigE, especially in relation to young speakers' variable use of r-liaison and consonant deletion in connected speech. This is because only very little variation was observed in the data.

\section{References}

Abercrombie, D. 1967. Elements of General Phonetics. Edinburgh: Edinburgh University Press.

Alam, F. and J. Stuart-Smith, 2011. Identity and ethnicity in /t/ in Glasgow-Pakistani highschool girls. In ICPhS XVII, Hong Kong, pp. 216-219. http://eprints.gla.ac.uk/71760. (viewed 13 July, 2015).

Awonusi, V., 2004. Some characteristics of Nigerian English phonology. In A. Dadzie, and V. Awonusi eds., Nigerian English: Influences and characteristics, pp. 203-241. Lagos: Concept Publication.

Brosnahan, L. F., 1958. English in Southern Nigeria. English Studies 39: 97-110.

Byrd, D., 1994. Relations of sex and dialect to reduction. Speech Communication 15: 39-54.

Carter, P., 2005. Prosodic variation in SLA: Rhythm in an urban North Carolina Hispanic community. University of Pennsylvania Working Papers in Linguistics 11.2: 59-71. http://repository.upenn.edu/cgi/viewcontent.cgi?article=1535\&context=pwpl（viewed 15th December, 2015).

Clopper, C. G. and D. B. Pisoni, 2005. Perception of dialect variation. In D. Pisoni and R. Remez, eds., The Handbook of Speech Perception, pp. 313-337. Oxford: Blackwell.

Docherty, G. J. and P. Foulkes, 2005. Glottal variants of /t/ in the Tyneside variety of English. In W. J. Hardcastle and J. M. Beck, eds., A Figure of Speech: A Festschrift for John Laver, pp. 173-197. London: Lawrence Erlbaum. 
Eckert, P., 2000. Linguistic Variation as Social Practice. Oxford: Blackwell.

Foulkes, P., 2006. Phonological variation: A global perspective. In B. Aarts \& A. M.S. McMahon (ed.), Handbook of English Linguistics, pp. 625-669. Oxford: Blackwell.

Foulkes, P. and G. J. Docherty, 2006.The social life of phonetics and phonology. Journal of Phonetics 34.4: 409-438.

Foulkes, P. and J. B. Hay, 2015. The emergence of sociophonetic structure. In B. MacWhinney and W. O'Grady, The Handbook of Language Emergence, pp. 292-313. West Sussex: Wiley Blackwell.

Guy, G., 1981. Syntactic and phonetic variation in Carioca Portuguese. PhD Thesis, The University of Pennsylvania.

Hannisdal, B. R., 2006. Variability and change in Received Pronunciation: A study of six phonological variables in the speech of television newsreaders. $\mathrm{PhD}$ thesis, University of Bergen.

https://www.bora.uib.no/bitstream/1956/2335/1/Dr.Avh.BenteHannisdal.pdf. (viewed 20 August, 2010).

Hay, J. and K. Drager, 2007. Sociophonetics. Annual Review of Anthropology 36: 89-103.

Honey, J., 1997. Sociophonology. In F. Coulmans, ed., The Handbook of Sociolinguistics pp. 92-106. Blackwell: Oxford.

Horvath, B. M., 1985. Variation in Australian English: the sociolects of Sydney. Cambridge: Cambridge University Press.

Huber, M. and T. Brato, 2008. The emergence of social varieties in Ghanaian English. Paper presented at Accents 2008: II International Conference on Native and Non-native Accents of English, Łodz, 2008. http://www.thorsten-brato.de. (viewed10 October, 2010).

Hudson, R. A., 1996. Sociolinguistics. 2nd ed. Cambridge: Cambridge University Press.

Jibril, M., 1982. Phonological variation in Nigerian English. PhD Dissertation, University of Lancaster.

Jibril, M., 1979. Regional variation in Nigerian spoken English. In E. Ubahakwe, ed., Varieties and Functions of English in Nigeria, pp. 43-53. Ibadan: African University Press.

Kendall, T. and D. Fridland, 2011. Variation in perception and production of mid front vowels in the U.S. Southern vowel shift. Journal of Phonetics 40: 289-306.

Kerswill, P., 1987. Levels of linguistic variation in Durham. Journal of Linguistics 23: 25-49.

Kerswill, P., 1985. A sociophonetic study of connected speech processes in Cambridge English: An outline and some data. Cambridge Papers in Phonetics and Experimental linguistics 4. http://www.esrc.ac.uk/myesrc/grants/RC00232227/read. (viewed March 10, 2009).

Kroch, A. S., 1978. Toward a theory of social dialect variation. Language in Society 7: 17-36. Labov, W., 1991. Sociolinguistic Patterns. Philadelphia: University of Pennsylvania Press. 
Labov, W., 1990. The intersection of sex and social class in the course of linguistic change. Language Variation and Change 2: 205-54.

Labov, W., 1966. The Social Stratification of English in New York City. Washington, D.C.: Centre for Applied Linguistics DC.

Labov, W., 1963. The social motivation of a sound change. Word 19: 273-309.

Laver, J., 1994. Principles of Phonetics. Cambridge: Cambridge University Press.

McCarthy, O., 2012. A sociophonetic study of the realization of word final velar plosives by female pupils in a Glasgow high school. M.Phil Thesis, University of Glasgow. http://theses.gla.ac.uk/3331/ (viewed 13th July, 2015).

Milroy, J., 1987. Language and Social Networks 2nd ed. Oxford: Blackwell.

Nolan, F., 2002. Intonation in speaker identification: an experiment on pitch alignment features. Forensic Linguistics 9.1: 1-21.

Nolan, F. and P. Kerswill, 1990. The description of connected speech processes. In S. Ramsaran, ed., Studies in the Pronunciation of English: A commemorative volume in honour of A. C. Gimson, pp. 295-316. London: Routledge.

Ohala, J., 1983. The origin of sound patterns in vocal tract constraints. In P. F. MacNeilage, ed., The Production of Speech, pp. 189-216. New York: Springer Verlag.

Oladipupo, R. O., 2014a. Aspects of Connected Speech Processes in Nigerian English. SAGE Open 4, 1-6.

http://sgo.sagepub.com/content/4/4/2158244014560527.full-text.pdf+html. DOI: $10.1177 / 2158244014560527$

Oladipupo, R. O., 2014b. Social and linguistic correlates of r-liaison in educated Yoruba English. Ife Studies in English Language 11.1: 1-13.

Oladipupo, R. O., 2014c. A Sociophonetic Investigation of Standard British English Connected Speech Processes in Nigerian English. Doctoral Dissertation. University of Ibadan, Nigeria.

Pike, K., 1948. Problems in the teaching of practical phonemics. Language Learning 1.2: 3-8.

Roach, P. and H. Widowson, 2001. Phonetics. Oxford: Oxford University Press

Schrimpf, N., 2013. Politics and dialect variation: A sociophonetic analysis of the Southern Vowel Shift in Middle TN.

http://www.linguisticsociety.org/files/3542-6849-1-SM.pdf. (viewed 13th July, 2015)

Scobbie, J., 2005. Flexibility in the face of incompatible English VOT systems. In C. T. Best, L. Goldstein and D. H. Whalen, eds., Laboratory Phonology 8. Berlin: Mouton de Gruyter.

Simo Bobda, A., 2007. Some segmental rules of Nigerian English phonology. English WorldWide 28.4: 279-310. 
Skandera, P. and P. Burleigh, 2005. A Manual of English Phonetics and Phonology. Tübingen: Gunter Narr Verlag.

Sogunro, B. O., 2012. A sociophonological analysis of Hausa English, Igbo English and Yoruba English varieties in Nigeria. PhD Thesis, University of Ibadan.

Stuart-Smith, J., 2004. Empirical evidence for the gendered production of /s/ in Glaswegian. Paper presented at Laboratory Phonology 9, Urbana-Champaign, University of Illinois.

Thomas, E. R., 2002. Sociophonetic approaches of speech perception experiments. American Speech 77: 115-147.

Trudgill, P., 1974. The Sociolinguistic Differentiation of English in Norwich. Cambridge: Cambridge University Press.

Warren, P., 2005. Patterns of late rising in New Zealand - intonational variation or intonational change? Language Variation and Change 17.2: 209-30.

\section{Appendix}

\section{TEST 1}

\section{Researcher}

1) Have you ever met Peter?

2) How many boys are there?

3) What do you know about the girl?

4) Sir, she is looking for you. teacher?

5) Why not ask him to do it?

6) Did he say something?

7) I want more food, please!

8) How many did you find?

9) Is he a young man?

10) Did you enjoy your launch?

11) Did he look sad?

12) Did they rob the Mall?

13) How did I jump?

14) What do you want from your husband?

15) Did you meet him at that time?

16) What can you say about their action?

17) What is the main duty of the police?

\section{The participant}

I've met Peter at the station

There are ten boys

She's a good girl

Why? Doesn't she know her

He won't do it

No, he kept quiet

Eeh! you mustn't over-eat

I found five

No, he is an old man

That was cold lunch

No, he seemed glad

No, but they robbed both banks

You jumped well

I want more of Him

I met him after a while

Their action is wrong

They maintain law and order 
18) Do you know the answer to the question? Know what? I don't have an Idea of it.

19) Where were you yesterday? I was at media event

\section{TEST 2}

A. Good morning. I'd like to inquire about the advertised car

B. Yes, we have the car here. Its features will amaze you

A. Is the information about it valid?

B. Yes, of course. It is equipped with power-assisted steering, which I suppose, is the most important piece of information that you need

A. Well, obviously, but...do you think it is really ice blue with darker blue inside?

B. Oh... yes, this is the exact colour of the car.

A. All right, then. Can I arrange a test drive for tomorrow?

B. Y..es, you can have it tomorrow... It'll cost you ten pounds in case you don't buy it

A. Ten pounds!! Could you rather make it five pounds?

B. Sorry, madam, we have a fixed price for all customers.

A. Well...in that case, I'll be there tomorrow. Goodbye.

B. Goodbye and God bless you. 